\title{
EFFECT OF PHOSPHITE FOLIAR FERTILIZATION ON THE NUTRIENT CONTENT OF FORCED SWEET PEPPER
}

\author{
Zsuzsanna Tóthné Taskovics ${ }^{1 *}$, András Kovács ${ }^{1}$, Attila Hüvely ${ }^{2}$ and András Palkovics ${ }^{3}$ \\ ${ }^{1}$ Department of Horticulture, Faulty of Horticulture and Rural Development, John von Neumann University, \\ Hungary \\ ${ }^{2}$ Department of Agriculture, Faulty of Horticulture and Rural Development, John von Neumann University, \\ Hungary \\ ${ }^{3}$ Department of Rural Development, Faulty of Horticulture and Rural Development, John von Neumann \\ University, Hungary \\ https://doi.org/10.47833/2020.1.AGR.011
}

\begin{abstract}
Keywords:
phosphate

sweet pepper

nutrient content

vitamin C

foliar fertilizer
\end{abstract}

\section{Article history:}

\begin{tabular}{lr} 
Received & 7 Nov 2019 \\
Revised & 28 Nov 2019 \\
Accepted & 5 Dec 2019 \\
\hline
\end{tabular}

\begin{abstract}
The goal of vegetable production now days is not only the increase of the yield, but to grow healthy food. To this aim environmentally conscious plant nutrition contributes greatly. One of the most important indicators of sweet pepper nutritional values is the vitamin $C$ content. One of the aims of the production of functional foods is to increase this value. In our research we were assessing the effect of phosphate containing foliar fertilizers on the vitamin $C$ content of sweet peppers.
\end{abstract}

\section{Introduction}

The goal of vegetable production now days is not only the increase of the yield, but to grow healthy food. Environmentally conscious plant nutrition and with the minimalization of chemicals we can improve the nutrient content of vegetables.

With the increased demand for functional foods growers are stimulated to produce vegetables which if consumed regularly have a beneficial effect on the consumers' health. Sweet pepper contains vitamins, carotenoids, and carbohydrates, but the most important is its vitamin $\mathrm{C}$ content [5]. Vitamin $\mathrm{C}$ is a strong antioxidant. It supports the effect of carotenoids and vitamin $\mathrm{E}$. It has a vital role in immune enhancement [6]. The consumption of sweet pepper is the base of healthy nourishment, and has a role as a functional food. It has a low energy content, its virtually free of fats, and contains water soluble dietary fibers [3].

Light intensity directly affects the quantity of vitamin $C$ transported to the pepper fruit. The higher the light intensity during the production, the higher the vitamin $\mathrm{C}$ content of the plant tissues, but high temperature affect the vitamin content negatively $[2,4]$.

In the summer months of the last few years extreme weather characterizes these months. Plant react with stress to sudden changes in temperature, which affects its nutrient transport, and ultimately the quality and quantity of the yield [1].

Our previous research showed that the application of phosphate containing fertilizers increase the vitamin $\mathrm{C}$ content of sweet peppers. To confirm our earlier findings we set up a new trial.

\footnotetext{
* Corresponding author. Tel.: +36 76517631

E-mail address: tothne.zsuzsanna@kvk.uni-neumann.hu
} 


\section{Method}

The trial was set up in a small airspace polytunnel at the Faulty of Horticulture and Rural Development, John von Neumann University. Plugs were planted in spring and autumn, so we could assess 2 production cycles in one year. Spring production started on $20^{\text {th }}$ of February 2018, the autumn production started on $8^{\text {th }}$ of August 2018. Plugs were planted in coir pith substrate. Plant density was 5 plants per square meter. The cultivar had a conical fruit shape with white flesh, because this type have the most production area in Hungary.

The treatments consisted of 5 treatments. An untreated, fertilizer 1 in 2 doses, and fertilizer 2 in 2 doses, 5 treatments altogether.

Fruit samples have been taken at harvest time in both production cycles, and have been analyzed in the Soil- and Plant Testing Laboratory of the Faculty.

\section{Results}

Laboratory samples have been analyzed for nutrient content, vitamin C content. Dry weight of the samples have been measured. Dry weight differed between growing cycles. The autumn production's dry weight was slightly lower than spring's (Figure 1.).

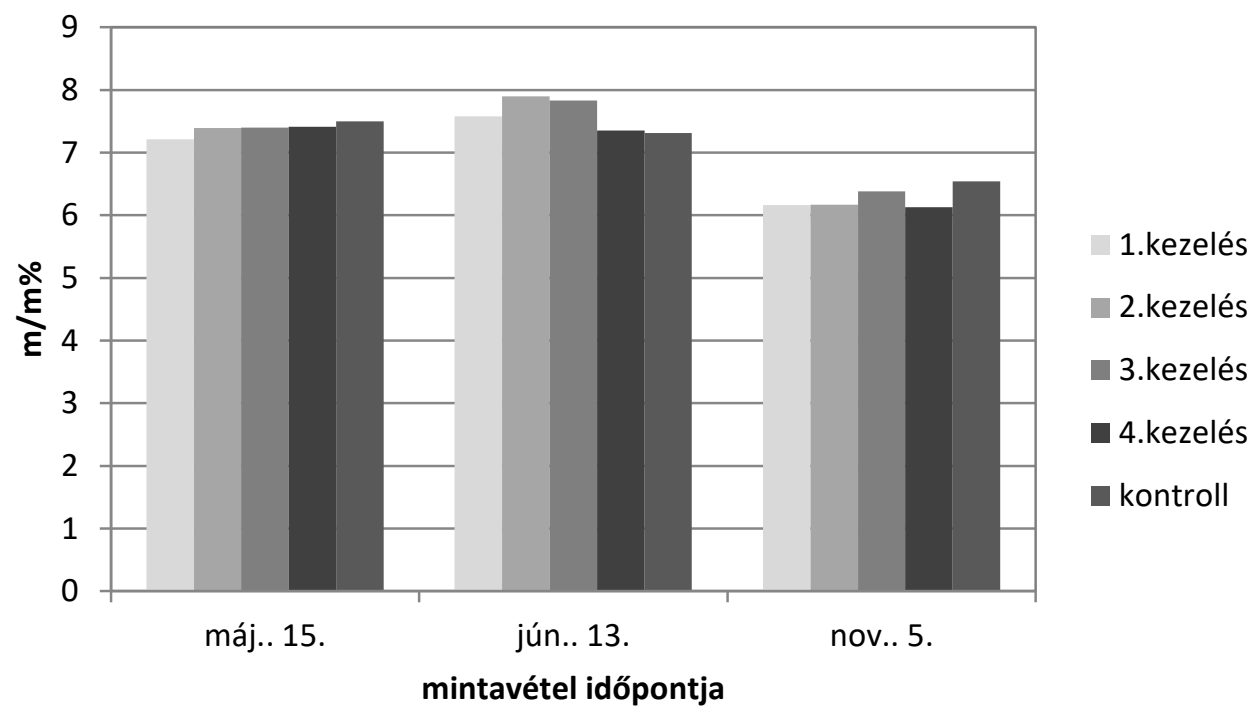

Figure 1. Dry weight of sweet pepper fruits in spring and autumn production at 3 different harvest time $(\mathrm{m} / \mathrm{m} \%)$.

This can be caused by the decrease of sunlight in the autumn cycle.

In regard of vitamin $\mathrm{C}$ content the outcome was variable in between the treatments and the time of harvest (Figure 2.). 


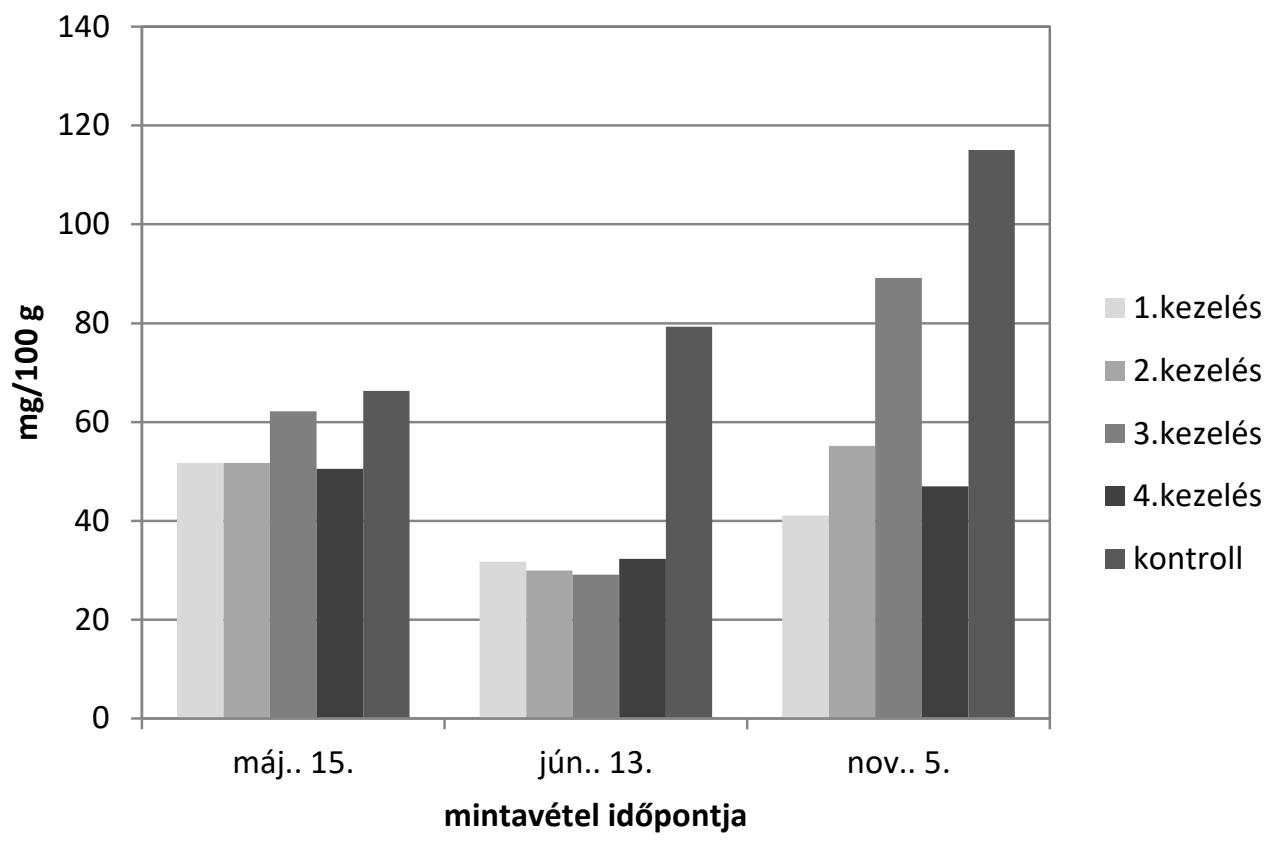

Figure 2. Vitamin C content of fruits at different harvest time $(\mathrm{mg} / 100 \mathrm{~g})$

In the autumn cycle 2 of the treatments had very high vitamin C content, this is opposite to other researchers' findings. Under lower light intensity the vitamin content of fruits should be lower too. Comparing the results of the spring and autumn production we could not see a significant difference.

In the case of nutrients the nitrogen, phosphorous, potash, calcium and magnesium contents were tested. We observed significant difference only in the case of calcium between harvest times (Figure 3.).

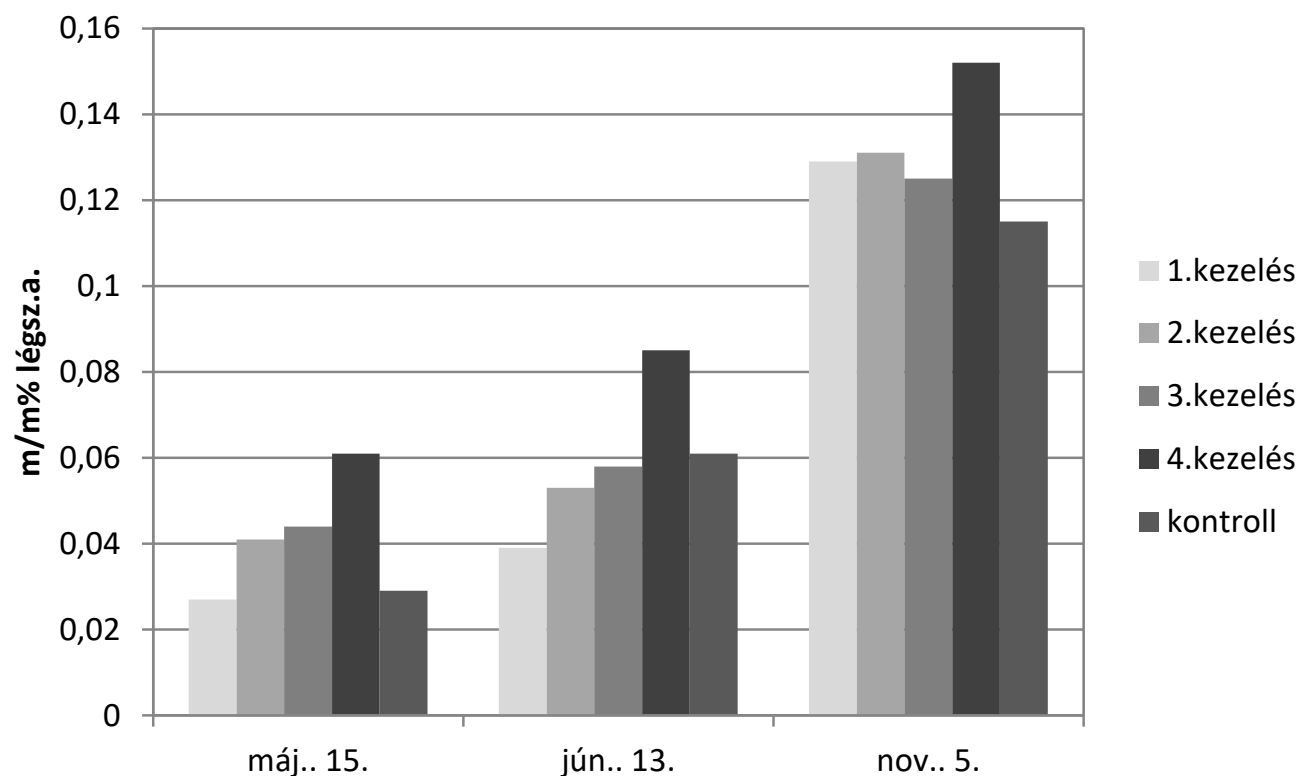

Figure 3. Calcium content of fruits at different harvest date. ( $\mathrm{m} / \mathrm{m} \%$ air dry)

This can be caused by the many rejected calcium-deficient fruits. Under high temperature plants cannot absorb calcium efficiently from the nutrient solution. In the case of some treatments - 
where we measured higher Ca content - the application of phosphate could decrease plant stress, and plants may absorbed Ca more efficiently.

The reliability of our results have been greatly impacted by the fact that the polytunnel had little airspace, the temperature was very high, while the relative humidity was low during the production cycle, especially in the spring production. Unfortunately we had no influence on these conditions.

\section{Discussion, conclusion}

The effect of different foliar fertilizers on the nutrient content of sweet pepper fruits is not supported by statistical evidence. Differences are most likely caused by environmental factors. In spring fluctuating temperature and high temperature, while low light intensity in autumn could be responsible for the differences in nutrient content. New trials should be set up under more optimal environmental conditions with other kinds of phosphate fertilizers.

\section{Acknowledgment}

Thank you for the support of the research carried out in the framework of the EFOP-3.6.2-162017-00012 „Developing a functional, healthy and safe food product chain model from field to table in a thematic research network". The project is funded by the Hungarian State and the European Union, co-financed by the European Social Fund, and is part of the Széchenyi 2020 program.

\section{References}

[1] Horinka T., Knipf R. (2007) Zöldségnövények hiánybetegségei és klimatikus hatások tünetei. Kertészek kis/Nagy Áruháza, Mórahalom. ISBN: 978-963-06-1861-8.

[2] Lee S. K., Kader A. A. (2000) Preharvest and postharvest factors influencing vitamin C content of horticultural crops. Postharvest Biology and Technology 20:207-220. DOI: 10.1016/S0925-5214(00)00133-2

[3] Lichthammer A. (2007) A paprika (Capsicum annuum) táplálkozás élettani vonatkozásai és helye az egészséges táplálkozásban. 5 .

[4] Richardson A. C., Marsh K. B., Boldingh H. L., Pickering A. H., Bulley S. M., Frearson N. J., Ferguson A. R., Thornber S. E., Bolitho K. M., Macrae E. A. (2004) High growing temperature reduce fruit carbohydrate and vitamin C in kiwifruit. Plant Cell Environ 27:423-435. DOI: 10.1111/j.1365-3040.2003.01161.x

[5] Terbe I., Hodossi S., Kovács A., Glits M. (2005) Zöldségtermesztés termesztőberendezésekben. Mezőgazda, Budapest. ISBN: 978-963-286-204-0.

[6] Varga Z., Gilingerné Pankotai M. (2008) Zöldségfélék bioaktív anyagainak hatása az emberi egészségre. Agrárunió 9:57-59. 